\title{
Current Therapy for Advanced Melanoma and a Look at Future Signaling Pathways to Target
}

\author{
Peter Chow BS ${ }^{a}$, Pablo Angulo DO ${ }^{b}$, Kasie Kudrewicz Adkins DO ${ }^{c}$ \\ aUniversity of Kansas School of Medicine, Wichita, KS \\ ${ }^{\mathrm{b}}$ Children's Specialty Center of Nevada, Las Vegas, NV \\ ${ }^{\circ}$ Group Health TriHealth Physician Partners, Cincinnati, OH
}

\section{ABSTRACT}

Metastatic melanoma is a heterogeneous tumor of the skin derived from melanocytes notorious for its resistance to various forms of systemic therapy. Many different types of monotherapies and combination therapies have been developed in recent years, each with their own setbacks, and drawbacks. This review article will provide an overview of current FDA approved drug therapies for stage III and IV metastatic melanoma, key signaling pathways they target, and mechanisms of drug resistance. This paper will then look at future therapy for metastatic melanoma with a particular focus on targeted therapy on embryonic and evolutionarily conserved pathways in metastatic melanoma, including notch, wnt, hippo, hedgehog signaling, among others.

\section{INTRODUCTION}

Melanoma is a deadly skin cancer arising from melanocytes, the cells in the basal layer of the epidermis responsible for forming the pigment in our skin, hair and eyes. Melanoma's incidence has continuously increased throughout the years. ${ }^{1} \quad$ Due to public awareness and advancements in diagnostic methods, cases of melanoma frequently are diagnosed earlier through surgical excision, and thus carry a good prognosis and 5-year survival rate. ${ }^{2}$ However, advanced metastatic stages of melanoma (III and IV) have proven to be difficult to treat, with traditional chemotherapeutic drugs like dacarbazine
(DTIC) proving ineffective. In more recent years, targeted therapy, most famously, vemurafenib, a drug that targets melanomas harboring a V600E mutation, have shown improvement and promise in treating metastatic melanoma. ${ }^{1}$ Even still, metastatic melanoma has proven resilient to new treatments with its unique, heterogenous resistance mechanisms, requiring new approaches to bypass resistance. ${ }^{3}$ 
CURRENT FDA APPROVED

IMMUNOTHERAPY AND CHEMOTHERAPY

FOR STAGE III AND IV MELANOMA

(Table 1)
Interferon alpha-2b

Traditional therapy for melanoma includes surgery, radiation and systemic therapy, the latter a category which encompasses chemotherapy and immunotherapy. ${ }^{4}$ Immunotherapy enhances the body's immune function to combat tumors. FDA approved management options for resected stage III melanoma immunotherapy includes interferon alpha-2b. Interferon alpha-2b has multiple actions in the body, including binding to cell receptors and subsequently initiating increased phagocytic activity of macrophages and increased cytotoxicity of lymphocytes. Interferon alpha-2b has shown benefit in relapse-free survival benefit (1.72 vs 0.98 years), but no significant difference in overall survival (OS). ${ }^{5}$

\section{Interleukin-2}

FDA approved immunotherapy options for stage IV melanoma includes interleukin-2 (IL-2). IL-2 is a T-cell growth factor.

Treatment with IL-2 carries only a $16 \%$ overall response rate with a $6 \%$ complete response. ${ }^{6}$

\section{Anti-CTLA-4 Antibody}

More recent research has focused on

activating adaptive and innate immune

responses against tumor antigens.

Ipilimumab is an FDA-approved

immunotherapy for stage IV melanoma. ${ }^{7}$ It is

a monoclonal antibody that blocks cytotoxic

T-lymphocyte-associated antigen 4 (CTLA-

4), which normally acts as an immune checkpoint in the body that inhibits $T$ cell activation. Therefore, by targeting CTLA-4, ipilimumab enhances $T$ cell activation and cytokine production. In a phase 3 randomized controlled study, ipilimumab significantly improved overall survival in metastatic melanoma. $^{8}$

Data suggested a $28 \%$ to $34 \%$ decrease in mortality rates in advanced melanoma patients who were treated with ipilimumab and a significant improvement in overall survival. ${ }^{7}$ However, drawbacks can include a potential vast and dangerous array of autoimmune side effects, including but not limited to: enterocolitis, hypophysitis, pancreatitis, leukopenia, hepatitis, and these drug toxicities can be treatment-limiting and life threatening. ${ }^{8,9}$

\section{$P D-1$ and $P D-L 1$ Inhibitors}

Programmed cell death protein 1 (PD-1) is a receptor expressed on lymphocytes that binds its ligand PD-L1 expressed on tumor cells. The PD-1/PD-L1 is an immune checkpoint interaction that ultimately leads to $T$ cell exhaustion and tumor cell evasion. ${ }^{10}$ Nivolumab is a monoclonal antibody developed to target PD-1, inhibiting its interaction with PD-L1, and potentiating immune responses against tumor cells. ${ }^{11}$ Clinical trials have shown promising results of nivolumab compared to other therapies ${ }^{11}$, and the efficacy of nivolumab combined with ipilimumab in a phase 3 clinical trial has shown significant regression when the two immune checkpoint blockers were combined when compared to either drug alone. ${ }^{4}$

\section{Chemotherapy}

Dacarbazine (DTIC) is the only FDA approved chemotherapy drug for the treatment of advanced melanoma. DTIC is believed to be an alkylating agent that adds methyl adducts onto DNA, inducing cytotoxic and antitumor effects. ${ }^{12}$ However, responses to it are low at $5-12 \%$, the responses to the treatment themselves do not last long, and it has not been proven to prolong overall survival. ${ }^{13,14}$ 


\section{SKIN}

Table 1. Overview of currently available immunotherapy and chemotherapy options for advanced melanoma

\begin{tabular}{|c|c|c|}
\hline Drug & Mechanism of Action & Common Side Effects \\
\hline $\begin{array}{l}\text { Interferon alpha- } \\
2 \mathrm{~b}\end{array}$ & $\begin{array}{l}\text { Increases macrophage } \\
\text { phagocytosis, increases cytotoxicity } \\
\text { of lymphocytes, and blocks } \\
\text { oncogene expression }\end{array}$ & $\begin{array}{l}\text { Flu-like symptoms, elevated transaminases, nausea, vomiting, diarrhea, } \\
\text { neutropenia, leukopenia, thrombocytopenia }\end{array}$ \\
\hline Interleukin-2 & T cell growth factor & Flu-like symptoms, hypotension, arrhythmias, nausea, vomiting, diarrhea, oliguria \\
\hline Ipilimumab & $\begin{array}{l}\text { Blocks CTLA-4 immune checkpoint } \\
\text { inhibition, causing enhanced T cell } \\
\text { activation and cytokine production. }\end{array}$ & Rash, nausea, diarrhea, fatigue, weight loss \\
\hline Nivolumab & $\begin{array}{l}\text { Blocks PD-1 and PD-L1 immune } \\
\text { checkpoint interaction between } \\
\text { tumor and T lymphocyte, ultimately } \\
\text { preventing tumor cell evasion. }\end{array}$ & $\begin{array}{l}\text { Fatigue, malaise, hyperglycemia, hypertriglyceridemia, hyponatremia, } \\
\text { lymphocytopenia. }\end{array}$ \\
\hline
\end{tabular}




\section{BRAF Inhibitors}

The BRAFV600 somatic missense mutation is in approximately $66 \%$ of malignant melanomas. ${ }^{15}$ The mutation entails a constitutively active RAS-RAF-mitogenactivated protein kinase (MAPK) pathway, a pathway that is in charge of cell growth and proliferation. BRAF inhibitors that are FDA approved for unresectable stage III melanoma and stage IV melanoma harboring a BRAFV600 mutation include vemurafenib and dabrafenib. Vemurafenib's initial efficacy and low toxicity profile were documented in a 2011 phase 3 randomized clinical trial by Chapman et al comparing vemurafenib to DTIC in patients harboring a BRAFV600 mutation. In the study, the overall survival of patients receiving vemurafenib compared to dacarbazine was $84 \%$ at 6 months with a relative risk of death reduction of $63 \% .{ }^{16}$ Another BRAF inhibitor, dabrafenib, was approved in 2013, and it showed similar results to vemurafenib. ${ }^{17}$

Due to mechanisms of resistance, the longevity of efficacy of a BRAF inhibitor has been called into question. The response duration to treatment ranges from 2 months to more than 18 months. ${ }^{18}$ Researchers have shown that melanoma has a diverse array of mechanisms of resistance to escape BRAF inhibitor drug therapy. In a study by Shi et al examining acquired resistance to melanoma BRAF inhibitor therapy, multiple mechanisms of resistance were detected from tumor samples from patients: an estimated $52 \%$ of melanomas escaped via MAPK reactivating mechanisms, $4 \%$ escaped via the phosphatidylinositol 3'-kinase (PI3K)-PTENAKT pathway, $18 \%$ escaped via both core pathways, and $26 \%$ of melanomas escaped in an unknown fashion. Additionally, when they were able to take samples from multiple tumors in the same patient, they discovered $81 \%(13 / 16)$ patients harbored multiple mechanisms of resistance. ${ }^{19}$

\section{MEK + BRAF Combination Inhibitors}

In order to further improve survival rates in melanoma patients harboring a BRAFV600 mutation, combination therapy targeting other aspects of the RAS-RAF-MAPK pathways have been believed to be a potential method to overcome escape pathways of melanoma cells to BRAF inhibitor monotherapy. Trametinib is an FDA approved targeted therapy option for patients who carry the BRAFV600E who have unresectable stage III melanoma or stage IV melanoma. Trametinib targets MEK, a protein downstream of BRAF. A phase 3 clinical trial showed the benefits of combining a BRAF inhibitor (dabrafenib) with the MEK inhibitor, trametinib. Robert et al's results show that combining dabrafenib with trametinib compared to vemurafenib alone yielded positive outcomes: overall survival rate at 12 months was $72 \%$ in combination treatment compared to $65 \%$ in vemurafenib alone. ${ }^{20}$ There are still patients who fail combination therapy though, and when they do fail they form a more aggressive, metastatic melanoma. ${ }^{21}$ Additionally, in many cases of combined MEK-BRAF inhibitor treatment, approximately $30 \%$ of patients still have signs of progressive disease at 6 months. ${ }^{22}$ 
Table 2. Overview of currently available targeted therapy for advanced melanoma

\begin{tabular}{|c|c|c|}
\hline \multicolumn{3}{|c|}{ FDA approved targeted therapy for stage III and IV melanoma } \\
\hline Drug & Mechanism of Action & Common Side Effects \\
\hline Vemurafenib & $\begin{array}{l}\text { Targets BRAFV } 600 \text { mutation in MAPK } \\
\text { pathway }\end{array}$ & $\begin{array}{l}\text { Fatigue, prolonged Q-T interval, hypertension, peripheral neuropathy, rash, } \\
\text { alopecia, skin photosensitivity, arthralgia, keratoacanthoma, }\end{array}$ \\
\hline Dabrafenib & $\begin{array}{l}\text { Targets BRAFV600 mutation in MAPK } \\
\text { pathway }\end{array}$ & Hyperglycemia, skin rash, fatigue, headache, lymphocytopenia, arthralgia \\
\hline Trametinib & $\begin{array}{l}\text { Targets MEK in patients with a } \\
\text { BRAFV600 mutation, a protein } \\
\text { downstream to BRAF in the MAPK } \\
\text { pathway }\end{array}$ & Rash, hypoalbuminemia, diarrhea, anemia, elevated transaminases \\
\hline
\end{tabular}

Table 3. Important melanoma signaling pathways

\begin{tabular}{|ll|}
\hline \multicolumn{1}{c|}{ Signaling pathways that are potential targets for future melanoma therapies } \\
\hline Pathway & Involvement in Melanoma \\
\hline KIT & A receptor that can be targeted upstream of the MAPK pathway \\
\hline PI3K/AKT & A pathway involved in tumor angiogenesis and invasion. \\
\hline Notch & Embryonic cell pathway that possibly promotes tumor chemoresistance, tumorigenesis and progression \\
\hline WNT & Related to melanoma tumor formation and metastasis \\
\hline Hippo & A pathway thought to contribute to melanoma invasion and metastasis. \\
\hline Hedgehog & Involved in spatiotemporal development in embryos as well as melanoma cell proliferation and metastasis. \\
\hline
\end{tabular}


THE PROMISING FUTURE OF

MELANOMA THERAPY (Table 3)

\section{KIT Inhibitors}

$\mathrm{KIT}$ is a transmembrane receptor tyrosine kinase upstream of the RAS-BRAF-MAPK pathway, and is in charge of cell survival and proliferation in melanocytes. ${ }^{23}$ Many melanomas on mucosal, acral, and sun damaged sites harbor KIT mutations. ${ }^{24}$ Thus, KIT inhibitors like imatinib can be a possible drug therapy. Guo et al's phase 2 trial of imatinib on KIT mutations in metastatic melanoma showed that imatinib demonstrated significant activity against patients with a KIT mutation. ${ }^{25}$ However, they do note imatinib's overall response rate $(23.3 \%)$ is much lower than that of vemurafenib, which had an $81 \%$ response rate in BRAF patients, indicating the KIT inhibitor has a lower specificity. In another study of imatinib treatment of metastatic melanoma, challenges in identifying appropriate patients for KIT inhibition treatment was highlighted. Compared to BRAF mutations, KIT mutations can be more widely distributed in the coding region, providing patient identification challenges in KIT inhibitor therapy. ${ }^{24}$ Thus, although KIT inhibitors have had meaningful treatment outcomes in melanoma, more research is required to enhance responsiveness to this targeted therapy's overall response rate.

\section{PI3K/AKT Pathway}

The PI3K (phosphatidylinositol 3 kinase)AKT-mTOR pathway is involved in cell proliferation, invasion, metabolism, and angiogenesis in normal and tumor cells. ${ }^{26}$ It is separate from the RAS-RAF-MAPK pathway. There are studies now elucidating the relationship between the MAPK and PI3K pathways and mechanisms of tumor resistance to targeted drug therapy. In patient cell lines who were resistant to a RAF or MEK inhibitor, the PI3K pathway was found to be frequently upregulated or persistent in response. ${ }^{26}$ Thus, co-targeting the PI3K and BRAF pathways can potentially enhance metastatic melanoma sensitivity and prevent drug resistance. So far, co-targeting of MEK and PI3K/mTOR pathways showed more effective inhibition of BRAF mutant melanoma cell lines compared to the BRAF and PI3K/mTOR cotargeting inhibition. ${ }^{27}$ More testing and in a wider number and range of patients is required to further elucidate the relationship.

Another protein involved in the PI3K pathway is phosphatase and tensin homolog deleted in from chromosome 10 (PTEN), a tumor suppressor gene. PTEN is a PI3K pathway inhibitor, and its loss has been associated with tumor development in 30$50 \%$ of melanomas. ${ }^{28,29}$ In Stahl et al's study of mice models, PTEN loss was associated with decreased apoptosis in melanoma cells and PTEN expression associated with increased apoptosis. ${ }^{30}$ Furthermore, there have been studies that show that BRAF mutant melanoma cells actually utilize PTEN loss in order to progress to metastatic melanoma. The combination of BRAF mutation and loss of PTEN is estimated in approximately $20 \%$ of melanomas. ${ }^{31}$ Thus, a more intricate understanding of PTEN expression, PI3K pathway, MAPK and their role in melanoma tumorigenesis will be useful for combating resistance.

\section{Notch Pathway}

The notch pathway is a new avenue in battling melanoma which holds promise in preventing chemoresistance. The notch pathway is an evolutionarily conserved embryonic cell pathway important for cell fate and differentiation. ${ }^{32}$ Studies have suggested that dysregulated notch signaling can prolong and confer life to cancer stem cells, which are thought to be important in tumor chemoresistance. ${ }^{33}$ Other studies 


\section{SKIN}

have shown that notch activation promotes melanoma tumorigenesis and progression. ${ }^{32}$ Thus, therapeutic benefit of targeting notch signaling includes preventing tumor angiogenesis, cancer stem cell depletion, and cell death. ${ }^{34}$ The notch receptor family consists of four transmembrane receptors (Notch 1-4). ${ }^{35}$ Recent research on melanoma cells correlate metastasis of melanoma cells with expression of $\mathrm{NOTCH} 4$ gene, suggesting this protein and the notch pathway can be a potential target of melanoma therapy. ${ }^{36}$ There is currently research on drug therapy that can target notch signaling in melanoma cells. Kaushik et al have demonstrated that Honokiol (a biphenolic organic compound) can target notch signaling, confirmed with decreased downstream effector target genes of notch: Hes-1, and cyclin D1. ${ }^{35}$

\section{WNT Signaling Pathway}

The WNT signaling pathway is important for cell proliferation, differentiation, migration, and many other processes of cell fate during embryonic development. ${ }^{37}$ Beta-catenin is a downstream transcription factor of the WNT pathway that can translocate to the nucleus for target gene expression. Understanding of the WNT signaling pathway in melanoma progression may be critical-studies have found canonical and noncanonical WNT signaling effect different stages of tumor progression, with canonical affecting melanoma formation and noncanonical affecting melanoma metastasis. ${ }^{38}$ There exists controversy in regards to the exact involvement WNT signaling has on melanoma behavior. One study showed loss of nuclear beta-catenin staining was associated with aggressive melanoma behavior, ${ }^{39}$ and another study showed that elevated levels of nuclear beta-catenin was associated with reduced proliferation of melanoma cells. ${ }^{40}$ Combined these findings suggest that $\mathrm{Wnt} /$ beta-catenin signaling is important for melanoma cell homeostasis, and if dysregulated, can lead to transformation of melanoma cells. ${ }^{41}$

\section{Hippo Signaling}

While many drug therapies and studies are focusing on the RAS-RAF-MAPK pathway in melanoma, fewer studies are focusing on targeting the invasive potential of melanoma cells. The mechanisms underlying melanoma invasion are presently poorly understood. The Hippo pathway (the Salvador-Warts-Hippo) is an evolutionarily conserved mechanism in charge of tissue and cell growth. ${ }^{42}$ Downstream in the Hippo pathway are YAP and TAZ effector proteins which are amplified in many cancers and promote epithelial-mesenchymal transition-a frequent hallmark of metastasis. ${ }^{43}$ In a model of skin reconstruct, YAP overexpression led to increased melanoma cell invasiveness, and YAP knockdown led to decreased metastasis potential. ${ }^{43}$ Thus, mutations in the Hippo pathway yield increased activation of YAP and TAZ, which promote metastasis regardless of BRAF mutation status in melanomas. ${ }^{42,44}$ Current research is examining verteprofin, ${ }^{44} \mathrm{a}$ molecule that inhibits YAP function and whether or not it can successfully regulate Hippo effector functions and subsequently melanoma invasion.

\section{Hedgehog Pathway}

Another way to target cancer stem cells involves the hedgehog signaling pathway. This is an evolutionarily conserved pathway in charge of spatiotemporal development in embryos. ${ }^{45}$ The pathway includes Smoothened G-protein coupled receptor-like receptor $(\mathrm{SMO})^{45}$ and downstream of SMO include many transcription factors including GLI1 and GLI2, both proven in recent years to help melanoma cell proliferation and metastasis. ${ }^{46,47}$ Microarray gene expression profiles of metastatic melanoma tumors 
showed elevated SMO, which correlated with overall decreased survival in melanoma patients. ${ }^{45}$ Promising studies have demonstrated that by selectively blocking SMO in the Hedgehog pathway with NVPLDE-225, melanoma growth is suppressed in vitro and in vivo. ${ }^{45,48}$

\section{CONCLUSION}

Melanoma is a heterogenous tumor capable of resisting drugs through escape mechanisms. Existing FDA approved monotherapies have mostly been unsuccessful in the treatment of metastatic melanoma. Emerging research targeting embryonically conserved pathways, among others, are showing promising solutions to beating this cancer.

\section{Conflict of Interest Disclosures: None}

Funding: None

\section{Corresponding Author:}

Peter Chow, BS

University of Kansas, School of Medicine

1010 N Kansas Street, Wichita, KS

pchow@kumc.edu

\section{References:}

1. Tang T, Eldabaje R, Yang L. Current Status of Biological Therapies for the Treatment of Metastatic Melanoma. Anticancer Res. 2016 Jul;36(7):3229-41. Review.

2. Paluncic J, Kovacevic Z, Jansson PJ, Kalinowski D, Merlot AM, Huang ML, Lok HC, Sahni S, Lane DJ, Richardson DR. Roads to melanoma: Key pathways and emerging players in melanoma progression and oncogenic signaling. Biochim Biophys Acta.
2016 Apr;1863(4):770-84.

3. Shi H, Hugo W, Kong X, Hong A, Koya RC, Moriceau G, Chodon T, Guo R, Johnson DB, Dahlman KB, Kelley MC, Kefford RF, Chmielowski B, Glaspy JA, Sosman JA, van Baren N, Long GV, Ribas A, Lo RS. Acquired resistance and clonal evolution in melanoma during BRAF inhibitor therapy. Cancer Discov. 2014 Jan;4(1):80-93.

4. Wolchok JD, Chiarion-Sileni V, Gonzalez R, Rutkowski P, Grob JJ, Cowey CL, Lao CD, Wagstaff J, Schadendorf D, Ferrucci PF, Smylie M, Dummer R, Hill A, Hogg D, Haanen J, Carlino MS, Bechter 0, Maio M, MarquezRodas I, Guidoboni M, McArthur G, Lebbé C, Ascierto PA, Long GV, Cebon J, Sosman J, Postow MA, Callahan MK, Walker D, Rollin L, Bhore R, Hodi FS, Larkin J. Overall Survival with Combined Nivolumab and Ipilimumab in Advanced Melanoma. $N$ Engl J Med. 2017 Oct 5;377(14):1345-1356.

5. Fox MC, Lao CD, Schwartz JL, Frohm ML, Bichakjian CK, Johnson TM. Management options for metastatic melanoma in the era of novel therapies: a primer for the practicing dermatologist: part I: Management of stage III disease. J Am Acad

Dermatol. 2013 Jan;68(1):1.e1-9; quiz 10-12.

6. Fox MC, Lao CD, Schwartz JL, Frohm ML, Bichakjian CK, Johnson TM. Management options for metastatic melanoma in the era of novel therapies: a primer for the practicing dermatologist: part II: Management of stage IV disease. J Am Acad

Dermatol. 2013 Jan;68(1):13.e1-13; quiz 26-8.

7. O'Sullivan Coyne G, Madan RA, Gulley JL.

Nivolumab: promising survival signal coupled with limited toxicity raises expectations. J Clin Oncol. 2014 Apr 1;32(10):986-8. 
8. Hodi FS, O'Day SJ, McDermott DF, Weber RW, Sosman JA, Haanen JB, Gonzalez R, Robert C, Schadendorf D, Hassel JC, Akerley W, van den Eertwegh AJ, Lutzky J, Lorigan P, Vaubel JM, Linette GP, Hogg D, Ottensmeier $\mathrm{CH}$, Lebbé $\mathrm{C}$, Peschel C, Quirt I, Clark JI, et al. Improved survival with ipilimumab in patients with metastatic melanoma. $N$ Engl J Med. 2010 Aug 19;363(8):711-23.

9. Weber J. Ipilimumab: controversies in its development, utility and autoimmune adverse events. Cancer Immunol Immunother. 2009 May;58(5):823-30.

10. Dolan DE, Gupta S. PD-1 pathway inhibitors: changing the landscape of cancer immunotherapy. Cancer Control. 2014 Jul;21(3):231-7.

11. Johnson DB, Peng C, Sosman JA. Nivolumab in melanoma: latest evidence and clinical potential. Ther Adv Med Oncol. 2015 Mar;7(2):97-106.

12. Marchesi F, Turriziani M, Tortorelli G, Avvisati G, Torino F, De Vecchis L. Triazene compounds: mechanism of action and related DNA repair systems. Pharmacol Res. 2007 Oct;56(4):275-87.

13. Garbe C, Eigentler TK, Keilholz U, Hauschild A, Kirkwood JM. Systematic review of medical treatment in melanoma: current status and future prospects. Oncologist. 2011;16(1):5-24.

14. Atkinson V. Medical management of malignant melanoma. Aust Prescr. 2015 Jun;38(3):74-8.

15. Davies H, Bignell GR, Cox C, Stephens P, Edkins S, Clegg S, Teague J, Woffendin
H, Garnett MJ, Bottomley W, Davis N, Dicks E, Ewing R, Floyd Y, Gray K, Hall S, Hawes R, Hughes J, Kosmidou V, Menzies A, Mould C, Parker A, et al. Mutations of the BRAF gene in human cancer. Nature. 2002 Jun 27;417(6892):949-54.

16. Chapman PB, Hauschild A, Robert C, Haanen JB, Ascierto P, Larkin J, Dummer R, Garbe C, Testori A, Maio M, Hogg D, Lorigan P, Lebbe C, Jouary T, Schadendorf D, Ribas A, O'Day SJ, Sosman JA, Kirkwood JM, Eggermont AM, Dreno B, Nolop K, et al. Improved survival with vemurafenib in melanoma with BRAF V600E mutation. $N$ Engl J Med. 2011 Jun 30;364(26):2507-16.

17. Hauschild A, Grob JJ, Demidov LV, Jouary T, Gutzmer R, Millward M, Rutkowski P, Blank CU, Miller WH Jr, Kaempgen E, MartínAlgarra S, Karaszewska B, Mauch C, Chiarion-Sileni V, Martin AM, Swann S, Haney P, Mirakhur B, Guckert ME, Goodman V, Chapman PB. Dabrafenib in BRAF-mutated metastatic melanoma: a multicentre, open-label, phase 3 randomised controlled trial. Lancet. $2012 \mathrm{Jul}$ 28;380(9839):358-65.

18. Flaherty KT, Puzanov I, Kim KB, Ribas A, McArthur GA, Sosman JA, O'Dwyer PJ, Lee RJ, Grippo JF, Nolop K, Chapman PB. Inhibition of mutated, activated BRAF in metastatic melanoma. $N$ Engl J Med. 2010 Aug 26;363(9):809-19.

19. Shi H, Hugo W, Kong X, Hong A, Koya RC, Moriceau G, Chodon T, Guo R, Johnson DB, Dahlman KB, Kelley MC, Kefford RF, Chmielowski B, Glaspy JA, Sosman JA, van BarenN, Long GV, Ribas A, Lo RS. Acquired resistance and clonal evolution in melanoma during BRAF inhibitor therapy. Cancer Discov. 2014 Jan;4(1):80-93. 
20. Robert C, Karaszewska B, Schachter J, Rutkowski P, Mackiewicz A, Stroiakovski D, Lichinitser M, Dummer R, Grange F, Mortier L, Chiarion-Sileni V, Drucis K, Krajsova I, Hauschild A, Lorigan P, Wolter P, Long GV, Flaherty K, Nathan P, Ribas A, Martin AM, Sun P, et al. Improved overall survival in melanoma with combined dabrafenib and trametinib. $N$ Engl $J$ Med. 2015 Jan 1;372(1):30-9.

21. Smalley KS, Fedorenko IV. Inhibition of $\mathrm{BRAF}$ and BRAF+MEK drives a metastatic switch in melanoma. Mol Cell Oncol. 2015 Mar 19;2(4):e1008291.

22. Long GV, Stroyakovskiy D, Gogas H, Levchenko E, de Braud F, Larkin J, Garbe C, Jouary T, Hauschild A, Grob JJ, Chiarion Sileni V, Lebbe C, Mandalà M, Millward M, Arance A, Bondarenko I, Haanen JB, Hansson J, Utikal J, Ferraresi V, Kovalenko $\mathrm{N}$, Mohr P, et al. Combined BRAF and MEK inhibition versus BRAF inhibition alone in melanoma. $N$ Engl J Med. 2014 Nov 13;371(20):1877-88.

23. Wehrle-Haller B. The role of Kit-ligand in melanocyte development and epidermal homeostasis. Pigment Cell Res. 2003 Jun;16(3):287-96.

24. Carvajal RD, Antonescu CR, Wolchok JD, Chapman PB, Roman RA, Teitcher J, Panageas KS, Busam KJ, Chmielowski B, Lutzky J, Pavlick AC, Fusco A, Cane L, Takebe N, Vemula S, Bouvier N, Bastian BC, Schwartz GK. KIT as a therapeutic target in metastatic melanoma. JAMA. 2011 Jun 8;305(22):2327-34.

25. Guo J, Si L, Kong Y, Flaherty KT, Xu X, Zhu Y, Corless CL, Li L, Li H, Sheng X, Cui C, Chi Z, Li S, Han M, Mao L, Lin X, Du N, Zhang X, Li J, Wang B, Qin S.
Phase II, open-label, single-arm trial of imatinib mesylate in patients with metastatic melanoma harboring c-Kit mutation or amplification. J Clin Oncol. 2011 Jul 20;29(21):2904-9.

26. Atefi M, von Euw E, Attar N, Ng C, Chu C, Guo D, Nazarian R, Chmielowski B, Glaspy JA, Comin-Anduix B, Mischel PS, Lo RS, Ribas A. Reversing melanoma cross-resistance to BRAF and MEK inhibitors by co-targeting the AKT/mTOR pathway. PLoS One. 2011;6(12):e28973.

27. Penna I, Molla A, Grazia G, Cleris L, Nicolini G, Perrone F, Picciani B, Del Vecchio M, de Braud F, Mortarini R, Anichini A. Primary cross-resistance to BRAFV600E-, MEK1/2- and PI3K/mTORspecific inhibitors in BRAF-mutant melanoma cells counteracted by dual pathway blockade. Oncotarget. 2016 Jan 26;7(4):3947-65.

28. Paluncic J, Kovacevic Z, Jansson PJ, Kalinowski D, Merlot AM, Huang ML, Lok HC, Sahni S, Lane DJ, Richardson DR. Roads to melanoma: Key pathways and emerging players in melanoma progression and oncogenic signaling. Biochim Biophys Acta. 2016 Apr;1863(4):770-84.

29. Wu H, Goel V, Haluska FG. PTEN signaling pathways in melanoma. Oncogene. 2003 May 19;22(20):3113-22.

30. Stahl JM, Cheung M, Sharma A, Trivedi NR, Shanmugam S, Robertson GP. Loss of PTEN promotes tumor development in malignant melanoma. Cancer Res. 2003 Jun 1;63(11):2881-90.

31. Dankort D, Curley DP, Cartlidge RA, Nelson B, Karnezis AN, Damsky WE Jr, You MJ, DePinho RA, McMahon M, Bosenberg M. Braf(V600E) cooperates with Pten loss to

July 2018 Volume 2 Issue 4 
induce metastatic melanoma. Nat Genet. 2009 May;41(5):544-52.

32. Pinnix CC, Herlyn M. The many faces of Notch signaling in skin-derived cells.

Pigment Cell Res. 2007 Dec;20(6):458-65.

33. Capaccione KM, Pine SR. The Notch signaling pathway as a mediator of tumor survival. Carcinogenesis. 2013 Jul;34(7):142030.

34. Koch U, Radtke F. Notch signaling in solid tumors. Curr Top Dev Biol. 2010;92:411-55.

35. Kaushik G, Venugopal A, Ramamoorthy P, Standing D, Subramaniam D, Umar S, Jensen RA, Anant S, Mammen JM. Honokiol inhibits melanoma stem cells by targeting notch signaling. Mol Carcinog. 2015 Dec;54(12):1710-21.

36. Lin X, Sun B, Zhu D, Zhao X, Sun R, Zhang $Y$, Zhang D, Dong X, Gu Q, Li Y, Liu F. Notch4+ cancer stem-like cells promote the metastatic and invasive ability of melanoma. Cancer Sci. 2016 Aug;107(8):107991.

37. Komiya Y, Habas R. Wnt signal transduction pathways. Organogenesis. 2008 Apr;4(2):68-75.

38. Kulikova, Ksenia \& Kibardin, Alexey \& Gnuchev, N.V. \& Georgiev, G.P. \& Larin, Sergey. (2012). Wnt Signaling Pathway and Its Significance for Melanoma Development. Sovremennye Tehnologii v Medicine. 2012. 107-111.

39. Bachmann IM, Straume O, Puntervoll HE, Kalvenes MB, Akslen LA. Importance of P-cadherin, beta-catenin, and Wnt5a/frizzled for progression of melanocytic tumors and prognosis in cutaneous melanoma. Clin Cancer Res. 2005 Dec 15;11(24 Pt1):8606-14.

40. Chien AJ, Moore EC, Lonsdorf AS, Kulikauskas RM, Rothberg BG, Berger AJ, Major MB, Hwang ST, Rimm DL, Moon RT. Activated Wnt/beta-catenin signaling in melanoma is associated with decreased proliferation in patient tumors and a murine melanoma model. Proc Natl Acad Sci U S A. 2009 Jan 27;106(4):1193-8.

41. Kovacs D, Migliano E, Muscardin L, Silipo V, Catricalà C, Picardo M, Bellei B.

The role of $W n t / \beta$-catenin signaling pathway in melanoma epithelial-to-mesenchymal-like switching: evidences from patients-derived cell lines. Oncotarget. 2016 Jul 12;7(28):4329543314.

42. Harvey KF, Zhang X, Thomas DM. The Hippo pathway and human cancer. Nat Rev Cancer. 2013 Apr;13(4):246-57.

43. Nallet-Staub F, Marsaud V, Li L, Gilbert C, Dodier S, Bataille V, Sudol M, Herlyn M, Mauviel A. Pro-invasive activity of the Hippo pathway effectors YAP and TAZ in cutaneous melanoma. J Invest Dermatol. 2014 Jan;134(1):123-132.

44. Sanchez IM, Aplin AE. Hippo: hungry, hungry for melanoma invasion. J Invest Dermatol. 2014 Jan;134(1):14-16.

45. O'Reilly KE, de Miera EV, Segura MF, Friedman E, Poliseno L, Han SW, Zhong J, Zavadil J, Pavlick A, Hernando E, Osman I. Hedgehog pathway blockade inhibits melanoma cell growth in vitro and in vivo. Pharmaceuticals (Basel). 2013 Nov 11;6(11):1429-50. 
46. Stecca B, Mas C, Clement V, Zbinden M, Correa R, Piguet V, Beermann F, Ruiz I Altaba A. Melanomas require HEDGEHOG-GLI signaling regulated by interactions between GLI1 and the RAS-MEK/AKT pathways. Proc Natl Acad Sci U S A. 2007 Apr 3;104(14):5895-900.

47. Alexaki VI, Javelaud D, Van Kempen LC, Mohammad KS, Dennler S, Luciani F, Hoek $\mathrm{KS}$, Juàrez $\mathrm{P}$, Goydos JS, Fournier PJ, Sibon C, Bertolotto C, Verrecchia F, Saule S, Delmas V, Ballotti R, Larue L, Saiag P, Guise TA, Mauviel A. GLI2-mediated melanoma invasion and metastasis. J Natl Cancer Inst. 2010 Aug 4;102(15):1148-59.

48. Jalili A, Mertz KD, Romanov J, Wagner C, Kalthoff F, Stuetz A, Pathria G, Gschaider M, Stingl G, Wagner SN. NVPLDE225, a potent and selective SMOOTHENED antagonist reduces melanoma growth in vitro and in vivo. PLoS One. $2013 \mathrm{Jul}$ 30;8(7):e69064. 